\title{
Income Smoothing Use Financing Loss Provision In Indonesia And Malaysia's Islamic Banks
}

\author{
Fadhilah Hanum Lubis ${ }^{1}$, Sigid Eko Pramono ${ }^{2}$, Saiful Anwar ${ }^{3}$ \\ ${ }^{1}$ Students of Postgraduate at Tazkia Islamic University College, Indonesia \\ ${ }^{2}$ Postgraduate Lecturers of Tazkia Islamic University College, Indonesia \\ ${ }^{3}$ Postgraduate Lecturers of Intitute Teknologi dan Bisnis Ahmad Dahlan Jakarta \\ ${ }^{*}$ Corresponding author: \\ Email: dilahanum.dh@gmail.com
}

\begin{abstract}
.
Rapid development of Islamic banks leads to the requirement to compete in order to show the best performance. Performance assessment can be seen from the profit information. Income smoothing through the use of Financing Loss Provision (FLP) is one method that can be applied in Islamic banking in an attempt to get income based on their goals. This research aims to investigate income smoothing practice by using FLP at both Indonesia and Malaysia's Islamic banks by applying mixedmethod approach. In this regard, quantitive method was used to measure panel regression by using Eviews in order to analyze income smoothing practice through FLP in both Indonesia and Malaysia than qualitative method was used through interviews with practitioners and sharia supervisors in Indonesia to get the data about the practice. The data in this research were taken from 11 Islamic banks in Indonesia and 19 Islamic banks in Malysia from 2011 to 2016. The results of the research reveal that Islamic banks in both Indonesia and Malaysia apply income smoothing by using FLP. The findings imply that Earning Before Taxes and Provision (EBTP) has significant positive effect on FLP. Moreover, the results of interviews indicate that Islamic banks in Indonesia do not apply income smoothing. However, there is an indication that they will lead to this condition. Therefore, it is suggested that the regulators will supervise the application of FLP by developing the investigation of this account in financial statement of the Islamic banks.
\end{abstract}

Keywords: Indonesia Islmic Bank, Malaysia Islamic Bank, Income Smoothing, Financing Loss Provision

\section{INTRODUCTION}

One of the development centers of the Islamic banking and finance industry in the world is the Southeast Asia region. In this area, there are two countries that are driving the development of this industry, namely Indonesia and Malaysia. The development of the Islamic banking and financial systems in the two countries has encouraged neighboring countries to participate in developing the Islamic financial industry [1]. The 2017 Islamic Finance Country Index (IFCI) [2] issued a ranking of the growth of the Islamic banking and finance industry in each country. Malaysia is in first place and Indonesia is in seventh place. This index is seen from several variables, namely the number of Islamic banks, the number of Islamic non-bank financial institutions, sharia compliance, Islamic financial assets, Muslim population, sukuk, http://ijstm.inarah.co.id 
education and culture, and Islamic laws and regulations in each of these countries. The following is the IFCI 2017 top ten ranking table:

Table 1. IFCI Top Ten in 2017

\begin{tabular}{lcccc}
\hline \multicolumn{1}{c}{ Country } & $\mathbf{2 0 1 7}$ & $\mathbf{2 0 1 6}$ IFCI & 2017 IFCI & 2016 IFCI \\
& IFCI & & & \\
\hline Malaysia & 1 & 1 & 79.25 & 77.77 \\
Iran & 2 & 2 & 78.42 & 77.39 \\
Saudi Arabia & 3 & 3 & 65.90 & 66.98 \\
United Arab Emirates & 4 & 4 & 38.02 & 36.68 \\
Kuwait & 5 & 5 & 35.20 & 35.51 \\
Pakistan & 6 & 9 & 24.30 & 18.89 \\
Indonesia & 7 & 6 & 23.98 & 24.21 \\
Bahrain & 8 & 8 & 21.96 & 21.90 \\
Qatar & 9 & 7 & 21.94 & 22.02 \\
Bangladesh & 10 & 10 & 16.73 & 16.15 \\
\hline Soure: & & & &
\end{tabular}

Source: Islamic Finance Country Index 2017

The growth of Islamic banking in Indonesia and Malaysia can be seen from bank scope data which shows the total assets of Islamic banks in Indonesia from 2011 to 2016 reached USD 48,398,441. Meanwhile, the total assets of Islamic banks in Malaysia from 2011 to 2016 reached USD 592,329,932. The development of this industry shows a symptom of increasing competition, so that management always wants to show the best performance in every action [3]. Assessment of a performance can be seen from earnings information. This is in line with what Dechow [4] states that earnings are a measure that summarizes the performance of a company which is arranged on an accrual basis and becomes the basis for corporate evaluation. This makes management tend to adopt a policy called earnings management to show the best performance.

According to Scott [5], earnings management is a manager's way of influencing earnings figures systematically and deliberately by choosing certain accounting policies that aim to maximize manager utility and firm value. There are four patterns implemented by companies in performing earnings management, namely: taking a bath, income minimization, income maximazation and income smoothing. Management most often uses income smoothing in managing earnings from accounting manipulation policies. Accounting manipulation policies, according to Dechow and Skinner [4], are not the same as fraudulent accounting policies. Fraudulent accounting practices are considered to violate accounting standards and regulations, while accounting manipulation is still within the bounds of accounting rules.

Income smoothing is used to make profits relatively stable and can neutralize the company's financial condition which tends to be uncertain [6]. Income smoothing 
policies or practices are often carried out using a financing loss provision instrument. The lack of definitive standards in determining the quality of financing provides opportunities for bank managers to exercise discretion or actions or policies that can have a major impact on the bank's income statement [7].

The international accounting standards committee, banking supervisors and bank managers see that there are differences in interests in the principles underlying the provision of credit loss provisions [8]. The accounting standards committee emphasizes the importance of transparency in presenting bank financial information at a certain time to other parties for decision making, while bank supervisors want banks to protect their financial conditions and avoid systematic risk of failure [9].

Financing loss provisionsarises from the possibility of the bank experiencing the risk of loss due to financing provided to other parties. Therefore, the bank sets aside a fee called a financing loss provision to overcome this. In the income statement, the provision is presented as a non-cash expense. If the financing turns bad and cannot be collected, the cost is set-off against financing loss reserves so that it will not affect net income [10]. Financing loss provisionsis often termed provision for doubtful debts, charges for bad and doubtful debts, impairment losses,

In Indonesia, the financing loss provisionsis better known as Penyisihan Penghapusan Aktiva Produktif (PPAP) and Cadangan Kerugian Penurunan Nilai (CKPN). Based on Indonesia Bank regulations, PPAP refers to the quality of credit owned by a bank. There are five types of credit quality, namely current, special mention, substandard, doubtful, and loss. The term PPAP was then changed to allowance for impairment losses (CKPN) in 2006 based on the 2006 revised PSAK 55. PPAP and CKPN have differences, namely, PPAP is based on Bank Indonesia regulations. Meanwhile, CKPN is only formed when the bank has objective evidence that the debtor has an impairment. This is based on the bank's assessment of the debtor. Therefore, each bank can have a different policy in establishing a provision reserve for credit extended. However, the bank's policies must still be based on the criteria set by the Indonesian Bank and Accounting Guidelines (PAPI) after the revision of PSAK 55 revised 2006 [11].

Although CKPN is not rule based, it is in accordance with PBI No.14 / 15 / PBI / 2012, banks are required to calculate the allowance for asset losses (PPA) which is PPAP. The rules used to calculate the PPA are the same as the previous PPAP calculation rules. If there is a difference between the PPA and the CKPN that has been established, this can have an impact on the minimum capital adequacy ratio (KPMM). If the calculated PPA value is greater than the CKPN that has been established, the bank is obliged to cover the deficiency by using capital so that it will be a deduction for capital in the KPMM calculation. Conversely, if the PPA value is equal to or less than the established CKPN, banks do not need to take PPA into account in calculating the KPMM ratio [11]. 
In Islamic banks, the financing loss provisionsis called financing loss provisions (FLP). In the income statement and balance sheet, the financing loss provisionscan be described as follows:

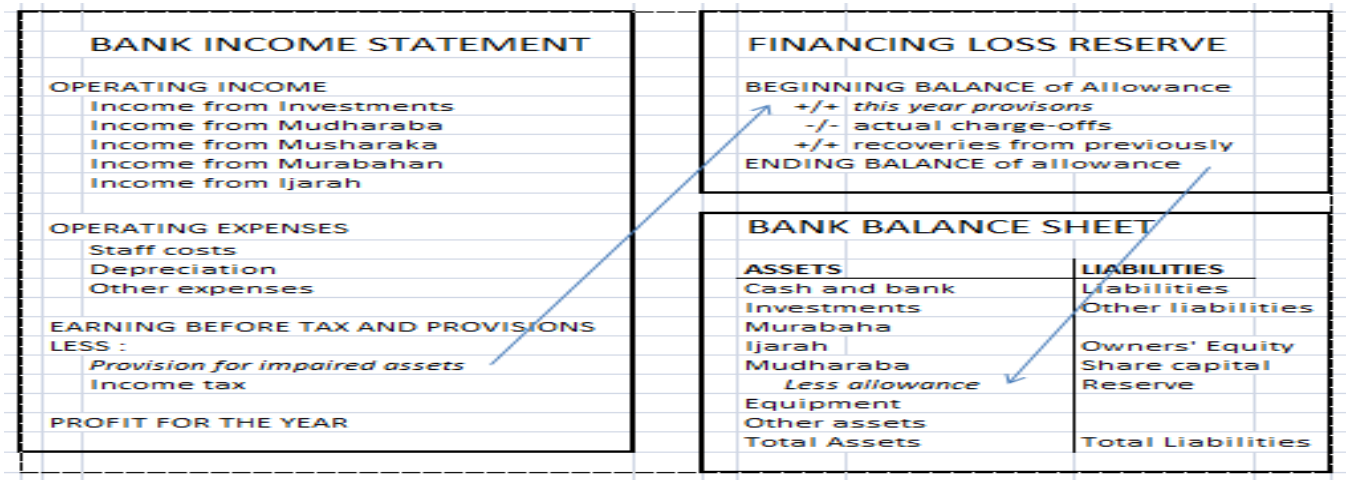

Source: Pramono (2015)

Fig. 1. FLP in The Income Statement and Balance Sheet

Research on income smoothing using loss provisions in Islamic banks shows a process that continues to develop and is not yet conclusive. Zoubi and Al-khazali [12] conducted research on 65 conventional banks and Islamic banks in the Gulf Cooperation Council (GCC). The results showed that Islamic banks carried out income smoothing with FLP in 2002-2003. Othman and Mersni [13] examined the practice of income smoothing in 21 Islamic banks, 18 conventional / Islamic banks and 33 conventional banks from seven countries in the Middle East during the 2000-2008 period. The results showed that Islamic banks use a loss provision for income smoothing. Researchers also found that there was no significant difference between Islamic banks and conventional banks in using provisions for income smoothing. Misman and Ahmad [14] conducted a study using 352 bank observation data in Malaysia for the 1993-2009 period. Researchers found that Islamic banks and conventional banks in Malaysia perform earnings management and capital management using FLP. This differs from the results of research conducted by Quttainah et. al. [15]. with a sample of banks in 11 countries. Researchers found that conventional banks use income smoothing than Islamic banks.

Taktak et. al. [16] also conducted a study on income smoothing practices in 66 Islamic banks for the 2001-2006 period at the GCC. The results showed that the managers of Islamic banks did not use the provision of losses for income smoothing. Ismail et. al. [17] conducted a study using 10 conventional banks that had Islamic bank products, showing that income smoothing was not use provisions, but using "security gains and losses". Archer et. al. [18] in their research stated that apart from using provisions, Islamic banks also use "profit equlization reserve" and "investment risk reserve".

However, there are differences of opinion regarding income smoothing or earnings management in Islamic business ethics. According to Ibrahim [19], income 
smoothing behavior is not in accordance with Islamic business ethics and is contrary to muamalah principles. In income smoothing, there is an element of deception (tadlis) and obscurity (gharar) because there are parties who hide information against other parties with the intention of deceiving others for ignorance of the information and if the action is proven, then this is prohibited in Islam, because it violates the principle "An taraaddin minkum". The hidden information can be in the form of quantity, quality, price, or time of delivery of the object being transacted. In the view of maqasid sharia, there are no provisions regarding the form of earnings management that are allowed by Islamic law. Whatever the underlying motivation is not in accordance with the teachings of Islam because it tends to lead to practices that benefit one party and harm the other, so there is an element of deception in it [20].

Muslim must uphold justice and honesty based on the orders and prohibitions that have been set by Allah, so that the information given is true, fair and free of deviations that will harm other parties. When viewed from Islamic business ethics, earnings management practices are not in accordance with the Al-Qur'an and Hadith Muliasari and Dianati [21]. However, in theory and practice earnings management is allowed, if it is not contrary to applicable accounting regulations[21]. Even though it is prohibited by sharia, the practice of income smoothing is very difficult to avoid by Islamic bank management [22]. Islamic banks should not practice income smoothing [23]. According to Setiawati and Na'im [24], apart from not being in accordance with Islamic business ethics, earnings management will bias financial reports and have an impact on decreasing the quality of financial reports, so that users of financial statements cannot believe it.

The pros and cons regarding earnings management in Islam have long been going on. In view of Islamic business ethics, earnings management actions are against the foundation of sharia. Because companies do it for personal gain, such as wanting to get bonuses, reducing taxes, presenting good performance in order to get investors and others. Companies are expected to carry out earnings management in order to have a positive impact on the company and not to harm other parties, but beneficial to all stakeholders without violating Islamic business ethics.

The earning management solution offered in answering these prosecutions is that companies can apply regulations such as Sarbanes Oxley to the maximum with good supervision and control. Companies must also apply Islamic business ethics in corporate governance in order to minimize possible fraud [21].

Based on this explanation, research of using financing loss provisions for income smoothing in Islamic banks is important so Islamic banks must more attention to Islamic business ethics in earnings management practices. However, there has been no research comparing the income smoothing using financing loss provisions (FLP) in Indonesia and Malaysia. In fact, these two countries have rapid development in the Asia Teggara region. 
The model used in this research is panel data regression with Eviews software to answer questions about the comparison of income smoothing using financing loss provisions (FLP) in Islamic banks of Indonesia and Malaysia. Previous researchers Packer and Zhu (2012), Taktak et. al. [16] and Fonseca and Gonzales [7] tested by observing changes in the provision of financing losses compared to the characteristics that affect income smoothing. These characteristics consist of earning before taxes and provision (EBTP), non performing financing (NPF), total financing (TF), equity (EQTA), and company size (SIZE). Then, the researcher will conduct an interview with an Islamic banking practitioner and sharia supervisor in Indonesia to find information about the practice of income smoothing and FLP in the banking sector.

\section{METHODS}

This study uses a mixed method approach, where quantitative methods are used in conducting panel regression to analyze the practice of income smoothing using FLP in Indonesia and Malaysia and qualitative methods are used in interviews with banking practitioners and sharia supervisors in Indonesia regarding this practice. The data used in this research are primary data and secondary data. Primary data were obtained from direct interviews with banker and DSN practitioners in Indonesia to obtain income smoothing information using FLP, while secondary data used in this study were financial statement data for Islamic banks in Indonesia and Malaysia. Data obtained from the bank scope for the period 2011-2016. The choice of this period was because in that year the development of Islamic banking in the two countries had increased. Analysis results can be more comprehensive and accurate if using a longer period, at least 5 years [25].

This study uses unbalanced panel data because the cross-section data used is not the same as the time-series data. The population in this study were all Islamic banks in Indonesia and Malaysia in 2011-2016. Based on data obtained from Bank Scope as of May 2017, there are 11 Islamic banks in Indonesia and 19 Islamic banks in Malaysia.The sampling technique used in this study is saturated sampling, which is a sampling technique in which all members of the population are used as samples. This is often done if the population is relatively small, less than 30 people. A saturated sample is also called a census, where all members of the population are sampled [26]. So this study uses the entire population, namely 11 Islamic banks in Indonesia and 19 Islamic banks in Malaysia, based on data obtained from bank scope as of May 2017.

The NPF variable is the balance sheet of bank i's non-performing financing in period $t$ normalized by total assets. Total financing (TF) is the ratio of total financing to total assets and represents a proxy for a bank's risk profile. Both the NPF and TF coefficients are expected to have a positive effect. The EBTP variable is net income before tax and bank provisions $i$ in period $t$, normalized by total assets. This variable is usually used in the previous literature as a proxy for earnings management practices. Under the inter-temporal income smoothing hypothesis, as suggested by, Beatty et. al. 
[27], Collins et. al. [28] and Ahmed et. al. [29], we expect a positive relationship between EBTP and FLP.

Previous studies also controlled for the effect of equity (EQTA) on FLP. Kim and Kross [30] and Ahmed et. al. [29] found low capital banks significantly reduced their FLP. The EQTA variable is close to the ratio of total bank capital in period $t$ to its total assets. Bank size (measured by log total assets) and dummy variables as control variables.

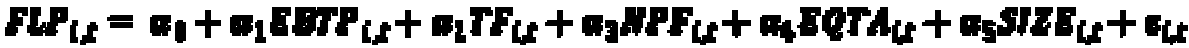

Where:

FLP $=$ FLP at the bank $i$ in year $t$ of total assets

EBTP $=$ Earning before taxes and provisions of total assets

$\mathrm{TF} \quad=$ Total financing of total assets

NPF $=$ Non perfomaming financing of total assets

EQTA $=$ Equity of total assets

SIZE = Company size

In testing the simultaneous effect of the dependent variable on the independent variable, this study uses panel data regression analysis which will be processed using Eviews 7. The researcher tests whether Islamic banks use FLP to distribute their profits. The econometric model used in this study is based on research conducted by Pe'rez et. al. [31], which examined the income smoothing dynamic provisioning of 142 Spanish banks in the period 1986-2002. This model introduces a variety of variables that reportedly explain a bank's FLP, including non-performing loans (NPF).

\section{RESULT AND DISCUSSION}

This study uses panel data from 11 Indonesian Islamic banks and 19 Malaysian Islamic banks in 2011-2016. Descriptive statistical analysis was used to determine the description of each research variable. Descriptive statistics for each variable can be seen from the minimum, maximum, mean, median and standard deviation values. Descriptive statistics of Islamic banks in Indonesia can be described in table form below:

Table 3.1. Descriptive Statistics of Indonesian Islamic Banks (USD)

\begin{tabular}{lrrrrrr}
\hline & FLP & \multicolumn{1}{c}{ EBTP } & \multicolumn{1}{c}{ TF } & \multicolumn{1}{c}{ NPF } & \multicolumn{1}{c}{ EQTA } & \multicolumn{1}{c}{ SIZE } \\
\hline Mean & 2,036 & 9,399 & $1,638,503$ & 150,271 & 180,769 & $2,356,736$ \\
Median & -1 & 3,955 & 349,983 & 31,181 & 81,800 & 522,447 \\
Max & 19,171 & 52,354 & $4,137,566$ & 569,164 & 475,769 & $5,867,202$ \\
Min & $-2,423$ & $-10,894$ & 42,156 & 793 & 11,791 & 99,983 \\
Std. & 5,945 & 17,879 & $1,707,130$ & 215,243 & 170,187 & $2,441,516$ \\
Dev. & & & & & & \\
\hline
\end{tabular}

Source: The data is processed using Eviews7 
Based on table 2, the dependent variable of financing loss provision (FLP) has a minimum value of $-2,423$, a maximum of 19,171 and an average of 2,036. FLP is a reserve formed by the bank in anticipating the risk of loss due to non-performing financing. The greater the FLP value, the greater the estimation of Indonesian Islamic banks on the risks caused by financing problems.

The independent variable EBTP has a minimum value of $-10,894$, a maximum of 52,354 and an average of 9,399. This shows that on average Indonesian Islamic banks can generate profits, but there are several Islamic banks that experience losses. The size of the profits generated shows the development of the bank and its ability to prosper the owner.

The independent variable TF has a minimum value of 42,156 , a maximum of $4,137,566$ and an average of $1,638,503$. This shows the total financing provided by Islamic banks in Indonesia. The independent variable NPF has a minimum value of 793, a maximum of 569,164 and an average of 150,271 . The NPF value shows the difficulties of a bank in managing financing which can affect bank profits. This suggests that Indonesian Islamic banks may experience financing problems.

The independent variable EQTA has a minimum value of 11,791, a maximum of 475,769 and an average of 180,769 . This shows the equity held by Indonesian Islamic banks. The greater the equity of a bank, the greater the power of the bank in covering the risk of losses that were not previously predicted.

The independent variable SIZE has a minimum value of 99,983, a maximum of $5,867,202$ and an average of 2,356,736. This shows the total assets held by Indonesian Islamic banks. Each bank has different total assets based on the operation and development of the bank.

Descriptive statistics of Islamic banks in Malaysia can be described in the form of the table below:

Table 3.2 . Descriptive Statistics of Malaysian Islamic Banks (USD)

\begin{tabular}{lrrrrrr}
\hline & FLP & \multicolumn{1}{c}{ EBTP } & \multicolumn{1}{c}{ TF } & \multicolumn{1}{c}{ NPF } & \multicolumn{1}{c}{ EQTA } & \multicolumn{1}{c}{ SIZE } \\
\hline Mean & $-6,390$ & 96,453 & $7,415,700$ & 82,030 & 634,299 & $8,700,420$ \\
Median & $-3,806$ & 41,254 & $3,704,396$ & 66,930 & 482,105 & $6,087,650$ \\
Max & 82,587 & 629,306 & $58,545,882$ & 397,675 & $3,642,284$ & $40,524,868$ \\
Min & $-69,620$ & $-31,252$ & 13,595 & 2,971 & 26,007 & 66,667 \\
Std. & 18,842 & 140,746 & $12,014,125$ & 77,921 & 675,138 & $9,125,414$ \\
Dev. & & & & & & \\
\hline
\end{tabular}

Source: The data is processed using Eviews7

Based on table 3 above, the dependent variable FLP has a minimum value of 69,620 , a maximum of 82,587 and an average of $-6,390$. The greater the FLP value, the greater the estimation of Malaysian Islamic banks on the risk caused by financing problems. 
The independent variable EBTP has a minimum value of -31,252, a maximum of 629,306 and an average of 96,453. This shows that Malaysian Islamic banks can generate profits on average, but there are some Islamic banks that experience losses.

The independent variable TF has a minimum value of 13,595 , a maximum of $58,545,882$ and an average of 7,415,700. This shows the total financing provided by Islamic banks in Malaysia. The independent variable NPF has a minimum value of 2,971 , a maximum of 397,675 and an average of 82,030 . The NPF value shows the difficulties of a bank in managing financing which can affect bank profits.

The independent variable EQTA has a minimum value of 26,007, a maximum of $3,643,284$ and an average of 634,229 . This shows the capital owned by Malaysian Islamic banks. The greater the equity of a bank, the greater the power of the bank in covering the risk of losses that were not previously predicted.

The independent variable SIZE has a minimum value of 66,667, a maximum of $40,524,868$ and an average of $8,700,420$. This shows the total assets held by Malaysian Islamic banks. Each bank has different total assets based on the operation and development of the bank.

\section{Robustness Test}

Verbeek [32] and Gujarati [33] reveal that panel data processing can use 3 (three) methods, namely the pooled least square method, the fixed effect method, and the random effect method. In estimating the regression model, the approaches that are often used from the three methods are the fixed effect method and the random effect method. Before deciding which model to use, a Chow-test is first performed to select between pooled least square and fixed effect methods. Then Hausmant-test to choose between the fixed effect method and the random effect method. Testing is done using Eviews7 with the following results:

Table 3.3 . Chow Test of Indonesian Islamic Bank

Redundant Fixed Effects Tests

Equation: Indonesia

Fixed effects cross-section test

\begin{tabular}{lrrr}
\hline \hline Effects Test & Statistics & df & Prob. \\
\hline \hline Cross-section F & 3.721764 & $(9.22)$ & 0.0057 \\
Chi-square cross-section & 34.234850 & 9 & 0.0001 \\
\hline \hline
\end{tabular}

Source: The data is processed using Eviews7

\section{Hypothesis}

H0: The selected model is the Pooled Effect Model.

H1: The model chosen is the Fixed Effect Model.

The results of the Chow test show that the Prob value in the F cross-section is 0.0057 , where the value is smaller than the alpha set at $5 \%$, so the decision to reject $\mathrm{H} 0$ 
is taken, namely the selected model is the fixed effect. After knowing the fixed effect model selected, then proceed to the Hausmant test, which is to compare the fixed effect model with the random effect model. Here are the results from the Hausman test.

Table 3.4. Hausman Test of Indonesian Islamic Bank

Correlated Random Effects - Hausman Test

Equation: Indonesia

Cross-section random effects test

\begin{tabular}{lrrr}
\hline \hline Test Summary & Chi-Sq. Statistics & Chi-Sq. df & Prob. \\
\hline \hline Random cross-section & 27.603158 & 5 & 0.0000 \\
\hline \hline
\end{tabular}

Source: The data is processed using Eviews7

\section{Hypothesis}

H0: The model chosen is the Random Effect Model.

H1: The model chosen is the Fixed Effect Model.

The results of the Hausmaan test show that the Prob value on the random cross section is 0.0000 , where the value is smaller than the alpha set at $5 \%$, so the decision to reject $\mathrm{HO}$ is taken, namely the chosen model is the fixed effect. The model chosen is the fixed effect because it has gone through two tests and the two chosen are the fixed effect.

Table 3.5 . Chow Test for Islamic Bank Malaysia

Redundant Fixed Effects Tests

Equation: Malaysia

Fixed effects cross-section test

\begin{tabular}{lrrr}
\hline \hline Effects Test & Statistics & df & Prob. \\
\hline \hline Cross-section F & 5.631883 & $(16.50)$ & 0.0000 \\
Chi-square cross-section & 74.189211 & 16 & 0.0000 \\
\hline \hline
\end{tabular}

Source: The data is processed using Eviews7

\section{Hypothesis}

H0: The selected model is the Pooled Effect Model.

H1: The model chosen is the Fixed Effect Model.

The results of the chow test show that the probability value in the cross section $\mathrm{F}$ is 0.0000 , where the value is smaller than the alpha set at $5 \%$, so the decision to reject $\mathrm{HO}$ is taken, namely the selected model is the fixed effect. After knowing the fixed effect model selected, then proceed to the Hausmant test, which is comparing the fixed effect model with the random effect model. Here are the results from the Hausman test. 
Table 3.6. Hausman Test for Islamic Bank of Malaysia

Correlated Random Effects - Hausman Test

Equation: Malaysia

Cross-section random effects test

\begin{tabular}{lcrc}
\hline \hline Test Summary & Chi-Sq. Statistics & Chi-Sq. df & Prob. \\
\hline \hline Random cross-section & 50.470177 & 5 & 0.0000 \\
\hline \hline
\end{tabular}

Source: The data is processed using Eviews7

\section{Hypothesis}

H0: The model chosen is the Random Effect Model.

H1: The model chosen is the Fixed Effect Model.

The results of the Hausmaan test show that the Prob value in the random crosssection is 0.0000 , where the value is smaller than the alpha set at $5 \%$, so the decision to reject $\mathrm{HO}$ is taken, namely the chosen model is the fixed effect. The model chosen is the fixed effect because it has gone through two tests and the two chosen are the fixed effect.

\section{Analysis of Indonesian Islamic Bank Regression Results}

Based on the results of the regression conducted on Islamic banks in Indonesia, the following results were obtained:

Table 3.7

Regression Results of Islamic Bank Indonesia

\begin{tabular}{lcccc}
\hline \multirow{1}{*}{ Variable } & \multicolumn{4}{c}{ Indonesia } \\
\cline { 2 - 5 } EBTP & Sign & Coefficient & t-statistic & Prob \\
TF & + & 1.348506 & 3.589011 & $0.0016^{* * *}$ \\
NPF & - & -0.102762 & -2.010857 & $0.0568^{*}$ \\
EQTA & + & 0.303428 & 4.863938 & $0.0001^{* * *}$ \\
SIZE & + & 0.087600 & 0.371913 & 0.7135 \\
C & + & 3.944107 & 3,749568 & $0.0011^{* * *}$ \\
Adj R-square & 0.778608 & & -3.974266 & 0.0006 \\
Num of obs & 37 & & & \\
F-stat & 10.04338 & & & \\
Prob (F-stat) & 0.000002 & & & \\
\hline Source: The da & & & &
\end{tabular}

Source: The data is processed using Eviews7

\section{Information:}

FLP:financing loss provisionsdivided by total assets; EBTP: earning before tax and provision by total assets; TF: total financing divided by total assets; NPF: nonperforming financing divided by total financing; EQTA: Equity divided by total assets; SIZE: $\log$ of total assets 
The model is estimated using panel data analysis with a fixed effect model, ***,**,* is a significant indication at the $1 \%, 5 \%$ and $10 \%$ levels.

\section{The Indonesian Islamic Bank Model

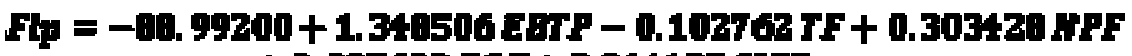 + 0. 097600 EqF + 3.94107 sHE}

This hypothesis testing is used to determine the practice of income smoothing using FLP. Table 4.10 shows that the value of Prob (F-statistic) $=0.000002$ is very significant and the test model used is good. Simultaneously the independent variable affects the dependent variable but partially or individually only the EBTP, TF, NPF, SIZE variables have a significant effect on the formation of FLP. Meanwhile, the EQTA variable does not have a significant effect on the allowance for FLP.

The test results on earnings before tax and Islamic bank provisions (EBTP) show that EBTP has a positive and significant coefficient on FLP ( $p$-value $=0.0016)$. The bigger (smaller) the EBTP, the bigger (smaller) the FLP set aside by the bank. This shows that Indonesian Islamic banks perform income smoothing using FLP in their operations. These results are consistent with the results of research by Ismail and Lay [34]; Bikker and Metzemakers [35]; Misman [14]; Othman and Mersni [13] who state that Islamic banks perform income smoothing using FLP.

The TF variable is negative and significant at the $10 \%$ level ( $\mathrm{p}$-value $=0.0568$ ) for FLP. This shows that the total financing provided by Islamic banks in Indonesia affects the FLP that is set aside. The results of this study contradict the results of the Taktak [16] study which showed that TF had a positive effect on FLP.

Testing of non-performing financing (NPF) shows that NPF has a positive and significant effect on FLP ( $p$-value $=0.0001)$. This shows that the NPF value of Indonesian Islamic banks has an effect on the allowance for the FLP value. The bigger (smaller) the financing problem, the bigger (smaller) the FLP is set aside. The results of this study are the same as those of Misman [14] and Taktak [16].

The SIZE variable is positive and significant ( $p$-value $=0.0011$ ) for FLP. It can be concluded that the total assets of Islamic banks in Indonesia affect the set aside FLP. The bigger (smaller) the size of the company, the bigger (smaller) the set aside for FLP. The results of this study are the same as Zoubi [12], Taktak [16] and Othman [13] which show that SIZE has a positive effect on FLP.

The EQTA variable is positive and insignificant ( $p$-value $=0.7135$ ) for FLP. This shows that the equity of Islamic banks in Indonesia does not affect the FLP set aside. The results of this study contradict the results of the research of Taktak [16] and Othman [13] which show that EQTA has a negative significance for FLP.

\section{Analysis of Malaysian Islamic Bank Regression Results}

Based on the results of the regression conducted on Islamic banks in Indonesia, the following results were obtained: 
Table 3.8. Regression Results of Malaysian Islamic Banks

\begin{tabular}{lcccc}
\hline \multicolumn{1}{c}{ Variable } & \multicolumn{4}{c}{ Malaysia } \\
\cline { 2 - 5 } EBTP & Sign & Coefficient & t-statistic & Prob \\
TF & + & 0.255565 & 3.031445 & $0.0039 * *$ \\
NPF & - & -0.013534 & -2.721917 & $0.0090^{* *}$ \\
EQTA & - & -0.196927 & -2.898421 & $0.0056 * *$ \\
SIZE & + & 0.238191 & 5.804297 & $0.0006^{* *}$ \\
C & - & -0.001234 & -0.338639 & 0.7364 \\
Adj R-square & 0.810094 & 0.015245 & 0.178666 & 0.8590 \\
Num of obs & 72 & & & \\
F-stat & 14.16820 & & & \\
Prob (F-stat) & 0.000000 & & & \\
\hline Source: The & & & & \\
\hline
\end{tabular}

Source: The data is processed using Eviews7

\section{Information:}

FLP: financing loss provisions divided by total assets; EBTP: earning before tax and provision by total assets; TF: total financing divided by total assets; NPF: nonperforming financing divided by total financing; EQTA: Equity divided by total assets; SIZE: $\log$ of total assets

The model is estimated using panel data analysis with a fixed effect model, ***, $* *$, $*$ is a significant indication at the $1 \%, 5 \%$ and $10 \%$ levels.

\section{The Malaysian Islamic Bank Model}

\section{$F \mathrm{pp}=0.015245+0.255565 \mathrm{EBF}-0.013534 \mathrm{FF}-0.196937 \mathrm{WFF}$ $+0.23191897-0.001734$ sta}

This hypothesis testing is used to determine the income smoothing practice using FLP. Table 4.11 shows that the value of Prob (F-statistic) $=0.000000$ is very significant and the test model used is good. Simultaneously the independent variable affects all dependent variables. However, partially or individually, only the variables EBTP, TF, NPF and EQTA have a significant effect on the formation of FLP, while the SIZE variable has no significant effect on the formation of FLP.

The test results on the profit before tax and provision of Malaysian Islamic banks (EBTP) show that EBTP has a positive and significant coefficient on FLP (pvalue $=0.0039$ ). The bigger (smaller) the EBTP, the bigger (smaller) the FLP set aside by the bank. This shows that Malaysian Islamic banks perform income smoothing using FLP in their operations. These results are consistent with the results of research by Ismail and Lay [34]; Bikker and Metzemakers [35]; Misman [14]; Othman and Mersni [13] who state that Islamic banks perform income smoothing using FLP.

The TF variable is negative and significant ( $p$-value $=0.0090)$ for FLP. This shows that the total financing provided by Islamic banks in Malaysia affects the FLP set aside. The smaller (bigger) the TF, the bigger (smaller) the FLP set aside by the 
bank. This result contradicts the results of the Taktak [16] study which showed that TF has a positive significance for FLP.

The test for non-performing financing (NPF) shows that the NPF is negative and significant for FLP ( $\mathrm{p}$-value $=0.0056$ ). This shows that the NPF value of Malaysian Islamic banks has an effect on the allowance for the FLP value. The smaller (bigger) the NPF, the bigger (smaller) the FLP set aside by the bank. This result is contrary to the results of the research of Taktak [16] and Misman [14] which show that NPF has a positive significance for FLP. The EQTA variable is positive and significant (p-value = 0.0000 ) for FLP. This suggests that the equity of Islamic banks in Malaysia affects the FLP set aside. The results of this study contradict the results of the research of Taktak (2010a) and Othman [13] which show that EQTA has a negative significance for FLP.

The SIZE variable is negative and insignificant $(\mathrm{p}$-value $=0.7364)$ for FLP. This shows that the total assets of Islamic banks in Malaysia do not affect the value of the set aside FLP. This contrasts with the results of the research of Taktak [16] and Othman [13] which show that SIZE has a positive effect on FLP.

\section{Research Interview Results}

Researchers conducted interviews with banking practitioners and sharia supervisor (DSN) in Indonesia regarding income smoothing using financing loss provisions(FLP). Interviews were conducted directly with each party. The results can be described as follows:

\section{Banking Practitioner}

The author has conducted interviews with repair practitioners who informed him that the bank has a Bank Business Plan (RBB) which guides the bank in shaping and managing profits. Everything was planned, except something unwanted, such as force majeure. Each bank account already has its own target. To achieve this target, the bank has estimated how much investment is needed, the amount of resources that will be used, both for increasing the competence of employee skills, the number of employees, and the costs to be incurred for each account. So, the bank already has a prediction of the annual profit that will be obtained.

Banks tend to want profits to increase consistently every year in accordance with the RBB. Therefore, the bank will carry out the predetermined earnings management by managing financial statements. There are several methods of earning management, one of which is income smoothing using PPAP and CKPN accounts or using (Profit Equalization Reserve / PER). PPAP and CKPN are contained in PSAK 55, while income smoothing using PER is found in Fatwa DSN No. 87. According to the informants, there is no income smoothing practice in the bank. However, what is done is financial report management in accordance with the RBB.

The Bank has also carried out financial reporting procedures in accordance with applicable standards. This is evidenced by the existence of an audit report from an external auditor who has been appointed by the Bank's Commissioner to ensure independence. Usually the bank is audited by KAP BIG FOUR. The auditor checks the 
financial statements in accordance with accounting standards and has materiality standards and standard errors depending on the circumstances of the auditee. Especially for banks that maintain public funds, this will be given more attention. Because the published audit reports are related to bank transparency which will increase public confidence.

\section{Sharia Supervisor}

Islamic banks have the main activity, namely channeling financing. This distribution can create credit risk which can affect the bank's profit statement. Islamic banks also have a displacement risk, namely, the risk of shifting Islamic bank customers to conventional banks or to other Islamic banks. This risk arises from competing interest rates in the market. Islamic banks that operate on the principle of profit sharing tend to experience fluctuations in the profit sharing rate which will make customers prefer conventional banks or other Islamic banks that have greater profits. This makes banks not want to have fluctuating profits. Banks tend to want stable profits, so income smoothing is needed.

DSN has issued fatwa no 87 regarding income distribution and third parties. This fatwa provides two methods, firstly, income smoothing, namely income smoothing without forming a profit adjustment reserve and secondly, income smoothing by forming a profit adjustment reserve (PER).

PER on the asset side (mudharabah and musyarakah) has the possibility of high moral hazard in the form of a subjective assessment of problem customers. If there are customers who experience difficulties, banks tend to provide assistance to these customers, the bank should treat all customers fairly.

Based on the interview results, to detect moral hazard or not, the bank is examined by an external auditor annually. The supervisor expects the auditors to pay attention to the existence of reserves made by banks.

\section{CONCLUSION}

This research was conducted to obtain empirical evidence of the practice of income smoothing using financing loss provisions (FLP) in Indonesian and Malaysian Islamic banks in 2011-2016. The analysis is carried out by examining the variables that affect financing loss provisions (FLP) using panel data analysis. The results showed that the Islamic banks of Indonesia and Malaysia practiced income smoothing by using FLP. Bank Islam Indonesia, Earning Before Taxes and Provisions (EBTP) has a positive and significant effect on income smoothing using financing loss provisions (FLP). Bank Islam Malaysia, Earning Before Taxes and Provisions (EBTP) has a positive and significant effect on income smoothing using financing loss provisions (FLP). The results of the interview informed that Islamic banks in Indonesia did not perform income smoothing, but there were indications that this would happen. 


\section{ACKNOWLEDGMENTS}

The authors are grateful to Tazkia Islamic University College at Indonesia, to Indonesia Central Bank, to Indonesia Banking Practitioner and to Indonesia Sharia Supervisor.

\section{REFERENCES}

[1] Rama, Ali., Analisis Deskriptif Perkembangan Perbankan Syariah di Asia Tenggara, The Journal of Tauhidinomics, 2015, Vol. 1 No. 2: 105-128.

[2] Islamic Finance Country Index - IFCI (2017), Dubai Islamic Bank, Global Islamic Finance Report 2017, 2017.

[3] Dwiatmini, Sesilia dan Nurkholis, Analisis Reaksi Pasar Terhadap Informasi Laba: Kasus Praktik Peralatan Laba Pada Perusahaan Yang Terdaftar Di BEJ, TEMA, 2001, Vol II : No.1, h.35-48.

[4] Dechow, P. M., dan Skinner, D.J, Earning Management: Reconciling the Views of Accounting Academics, Pracitioners, and Regulators, 2000, February.

[5] Scott, William R, Financial Accounting Theory, International Edition, United States: Prentice-Hall Inc, 2009.

[6] Sulistiawan, Dedhy. Januarsi, Yeni. Alvia, Liza, Creative Accounting: Mengungkap Manajemen Laba dan Skandal Akuntansi. Jakarta: Salemba Empat, 2011.

[7] Fonseca, A.R., dan Gonzalez, F, Cross-Country Determinants of Bank Income smoothing by Managing Loan-Loss Provisions, Journal of Banking \& Finance, 2008, Vol.32 (2), 217-228.

[8] Curcio, D., dan Hasan, I., Earning and Capital Management and Signaling: The Use of Loan Loss Provisions by European Banks. The European Journal of Finance, 2013, pp.1-25.

[9] Bushman, R., dan Williams, C., Accounting Discretion, Loan Loss, Provisioning, and Discipline of Banks' Risk-Taking, Journal of Accountingg and Economics, 2012, Vol. 54 (1), 1-18.

[10] Rose, P. S, Commercial Bank Management. (5th ed). New York: McGraw-Hill Irwin, 2002.

[11] Yumanita et. al., Kajian Kemungkinan Implementasi Kebijakan Dynamic Provisioning di Indonesia, Working Paper Bank Indonesia, 2013.

[12] Zoubi, T.A., dan Al-Khazali, O., Empirical Testing of The Loss Provisions of Banks in The GCC region, Managerial Finance, 2007, Vol.33 (7)., 500-511.

[13] Othman dan Mersni. (2014), The Use of Discretionary Loan Loss Provision by Islamic Banks and Conventional Banks in The Middle East Region: A Comparative Study, Studies in Economics and finance, 2014, Vol.31 No.1 pp.106-128.

[14] Misman, F. N., dan Ahmad, W., Loan Loss Provisions: Evidance from Malaysian Islamic and Conventional Banks, International Review od Business Research Papers, 2011, Vol. 7 (4), 94-103.

[15] Quttainah, M.A., Song, L., dan Wu, Q., Do Islamic Banks Employ Less Earnings Management? Paper for Economic Research Forum, Oct, 2011. 
[16] Taktak, N.B., Zouari, S.B.S., dan Boudriga, A, Do Islamic Banks Use Loan Loss Provisions To Smooth Their Result? Journal of Islamic Accounting and Business Research, 2010a, Vol. 1 (2), 114-126.

[17] Ismail, A.G., Shaharudin, R.S., dan Samudhram, A.R., Do Malaysian Banks Manage Earnings Through Loan Loss Provisions?, Journal of Financing Reporting and Accounting, 2005, Vol. 10 (1), 147-162.

[18] Acher, S., Karim, R.A.A., and Sundararajan V, Supervisory, Regulatory, and Capital Adequacy Implications of Profit-Sharinf Investment Accounts in Islamic Finance, Journal of Islamic Accounting \& Business Research, 2010, Vol.1 (1), 10-31.

[19] Ibrahim, Income Smoothing dan Implikasinya Terhadap Laporan Keuangan Perusahaan dalam Etika Ekonomi Islam, Jurnal Media Syariah, 2010, Vol. XII. 24.

[20] Obid dan Demikha, Earnings Management: Islamic Perspective, Asia Pacific Journal of Accounting and Finance, 2011, Vol 2 (1).

[21] Muliasari, I. and Dianati, D., Manajemen Laba dalam Sudut Pandang Etika Bisnis Islam,. Jurnal Akuntansi dan Keuangan Islam, 2014, Vol.2, No.2

[22] Saringat, S.M., Haron, R., \& Tahir, H.H.M, Income smoothing and Islam: an Evidence from Malaysian Shariah Compliant Companies. Internationak Journal of Social Science and Humanity, 2013.

[23] Zahara dan Sylvia Veronica Siregar, Pengaruh Rasio CAMEL Terhadap Manajemen Laba di Bank Islam, Jurnal riset Akuntansi Indonesia, Vol. 12, No.2, 2009.

[24] Setiawati dan Na'im., Manajemen Laba. Jurnal Ekonomi dan Bisnis Indonesia, 2000, Vol 15 (4), 424-441.

[25] Stolowy, H., dan Breton, G. 2004. Accounts Manipulation: A Literature Review and Proposed Conceptual Frameworl. Review of Accounting \& Finance, Vol. 3 (1), 5-66.

[26] Sugiyono, Metode Penelitian Bisnis. Alfabeta : Bandung, 2008.

[27] Beatty, A.L., Ke, B., and Petroni, K. R., Earnings Management to Avoid Earnings Declines Across Publicly and Privately Held Banks, The Accounting Review, 2000, Vol. 77 (3), 547-570.

[28] Collins, J. H.m Shackelford, D. A.m dan Wahlen, J. M, Bank Differences in The Coordination of Regulatory Capital, Earnings, and Texes, Journal of Financial Economics, 1995, Vol. 87, 357-373.

[29] Ahmed, A.S., Takeda, C., and Thimas, S, Bank Loan Loss Provisions: A Reexamination of Capital Management, Earnings Management and SIGNaling Effects, Journal of Accounting and Economics, 1999, Vol. 28, 1-25.

[30] Kim, M., dan Kross, W, The Impact of The 1989 Change in Bank Capital Standards on Loan Loss Provisions and Loan Write-offs, Journal of Accounting and Economics, 1998, Vol. 25, 69-100.

[31] Perez, D., Salas-Fumas, V. Dan Saurina, J, Do Dynamic Provisions Reduce Income Cmoothing Using LLP? Banco De Espana, Documentos de Trabajo, 2011, No. 1118.

[32] Verbeek, M, A Guide to Modern Economics. New York: John Wiley, 2000

[33] Gujarati, D. N, Basic Econometrics (Fourth ed.) New York: McGraw Hill, 2003

[34] Ismail, A.G., dan Be Lay, A.T., Bank Loans Portofolio Composition and The Disclosure of Loan Loss Provision: an Empirical Evidence of Malaysian Banks, Asian Review of Accounting, 2002, Vol. 10 (1), 147-162. 
[35] Bikker, J.A., dan Metzemakers, P., Bank Provisioning Behaviour and Procyclicality, Journal of International Financial Markets, Institutions and Money, 2005, Vol. 15, 141-157.

http://ijstm.inarah.co.id 